\title{
PENGARUH PENAMBAHAN LIMBAH PLASTIK JENIS THERMOSETTING TERHADAP MUTU BATA RINGAN (HEBEL)
}

\author{
Supriyadi $^{1, *)}$, Kusdiyono ${ }^{1)}$, Herry Ludiro Wahyono ${ }^{1)}$, Marchus Budi Utomo ${ }^{1)}$, \\ Imam Nurhadi ${ }^{1)}$ \\ ${ }^{1)}$ Jurusan Teknik Sipil Politeknik Negeri Semarang \\ Jln. Prof. H. Soedarto, S.H., Tembalang, Kota Semarang 50275 \\ ${ }^{*}$ Email: supriyadi083@yahoo.com; kusdiyono110456@gmail.com
}

\begin{abstract}
At this time, plastic is a material that is needed by the wider community and its impact is also extraordinary after the plastic is used in everyday life which can cause serious problems if the management is not done properly. The problem of plastic waste does not only occur in the city of Semarang, but also in other cities, so that the Ministry of Environment and Forestry to impose a program to use paid plastic bags in the short term. But this is only to deal with problems in the short term. In the long run, it will not solve the problem of "plastic waste", because the policy actually encourages people to buy plastic which, of course, will add a new burden on the community to buy it. The results showed that the compressive strength of light brick with the model / type of BN s.d. B10.0 with 10 variations of the mixture of the addition of plastic waste starting from (1.0 to 10.0)\% to the weight of Portland Cement (PC) there is a decrease in the average compressive strength. The lowest was the addition of $10.0 \%$ plastic waste with an average compressive strength of $9.88 \mathrm{~kg} / \mathrm{cm}^{2}$. The regression equation obtained $Y=0.042 \mathrm{X}^{2}-1.177 \mathrm{X}$ +18.84 with a correlation value $R^{2}=0.934$, meaning that the addition of plastic waste ranging from (1.0 to 10.0)\% of the weight of Portland Cement (PC) has the effect of "very strong "against the compressive strength. So we can get a picture that by adding the addition of plastic waste affects the compressive strength decreases. So that it can be investigated with other compositions by adding Fly Ash and sand made with a mixture ratio of 1 PC: 2 Aggregate (Sand and Fly Ash), with the hope that this Fly Ash waste can also be used for lightweight brick building elements.
\end{abstract}

Kata kunci : plastic waste, compressive strength, lightweight brick

\section{PENDAHULUAN}

Bahan plastik dapat dibagi menjadi 2 golongan dasar ditinjau dari struktur molekulnya, yaitu : bahan thermoplast dimana bersifat dapat diulang-ulang untuk dilembekkan dan dikeraskan dengan jalan memanasi dan mendinginkan, dan thermosetting bersifat mengeras setelah dibentuk yang tidak dapat dilembekkan lagi dengan cara pemanasan. Plastik merupakan bahan yang penting dalam bidang konstruksi karena memberikan sifat yang luas dalam pemakaian seperti : tahan korosi, tahan air, ringan, liat serta mudah dibentuk menjadi bentuk-bentuk yang sulit. Karena bahan plastik cukup banyak jenisnya, dan jenis satu dengan lainnya berbeda sifatnya serta memberikan keuntungan 
yang berbeda, maka bahan ini dapat dipakai sebagai bahan bangunan (PEDC, 1987).

Pada waktu ini, plastik merupakan bahan yang sangat dibutuhkan oleh masyarakat luas, namun dampaknya juga luar biasa setelah plastik itu dipergunakan yang dapat menimbulkan permasalahan serius apabila dalam pengelolaannya tidak dilakukan secara benar. Walikota Semarang pada 24 April 2016 dalam rangka sosialisai Perda No.6 Tahun 2012 menyampaikan bahwa di tingkat internasional, negara kita menduduki peringkat kedua penghasil sampah plastik setelah Tiongkok. Dari data terakhir pada tahun 2015, Indonesia menghasilkan sampah plastik mencapai 187,2 ton. Salah satu contoh penghasil sampah plastik adalah investasi swasta di bidang retail di mana jumlah gerai sebanyak 32.000 gerai yang menghasilkan sampah/kantong plastik sebanyak 9,6 juta lembar per hari. Sementara persoalan sampah sudah menjadi masalah serius di Kota Semarang sampai produksi sampah di Kota Semarang mencapai 1.200 ton/hari. Di beberapa wilayah, bahkan masalah sampah sudah menjadi persoalan yang meresahkan warga. Disamping juga akibat persoalan tempat pembuangan sampah (TPS) muncul persoalan horisontal yang mengakibatkan terpecah belahnya kerukunan warga. Yang berarti plastik ini apabila tidak dikelola dengan baik akan menimbulkan masalah besar dikemudian hari.
Permasalahan plastik ini tidak hanya disampaikan oleh Wali Kota Semarang saja, akan tetapi juga oleh Kementerian Lingkungan Hidup dan Kehutanan sampai memberlakukan program pemakaian kantong plastik berbayar dalam jangka pendek. Hal ini untuk menangani permasalahan dalam jangka pendek saja. Namun dalam jangka panjang, justru tidak akan menyelesaikan masalah "sampah plastik", lantaran kebijakan tersebut justru mendorong masyarakat untuk membeli plastik yang sudah barang tentu akan menambah beban baru masyarakat untuk membelinya (Suara Merdeka, 2016).

Contoh permasalahan plastik tidak hanya terbatas seperti diatas saja, akan tetapi menurut Lampung Pos Minggu, 15 Mei 2016 bahwa terjadinya banjir jalan protokol di Kota Metro saat hujan turun, ternyata disebabkan tersumbatnya aliran drainase tertutup oleh sampah. Dinas Pekerjaan Umum menemukan tumpukan sampah plastik dan terjadi sendimentasi pada saluran air tertutup tersebut. Namun, kondisi itu tampaknya tidak bisa segera diatasi karena keterbatasan dana untuk membongkar trotoar keseluruhannya.

Berdasarkan permasalahan diatas, perlu kiranya limbah plastik ini dimanfaatkan untuk dibuat menjadi suatu bahan bangunan seperti bata beton atau Bata Ringan (Hebel) dengan cara melalui penelitian seberapa besar pengaruh penambahan variasi limbah plastik terhadap kekuatan tekan Bata Ringan. Dalam penelitian ini dibuat Bata Ringan dengan 10 variasi 
campuran mulai dari (1 s.d. 10)\% terhadap berat Pasir (Agregat) pada campuran Bata Ringan (1PC : 2 PS). Agar mempunyai berat yang ringan ditambahkan bahan Foam Agent sebagai pembentuk pasta.

Penelitian ini dimaksudkan untuk mengukur pengaruh penambahan variasi campuran limbah Plastik terhadap kekuatan tekan Bata Ringan. Sedang tujuan yang ingin dicapai adalah untuk mendapatkan kekuatan tekan Bata Ringan yang pada berbagai macam variasi campuran dapat memenuhi persyaratan umum Bata Beton (Bata Ringan / Hebel) seperti dalam SNI 03-0349-1989. Hasil penelitan diharapkan masyarakat dapat memanfaatkan Limbah Plastik untuk dapat dibuat Bata Ringan disamping dapat memecahkan persoalan sampah yang serius dimasyarakat.

Untuk mewujudkan pengaruh variasi campuran limbah plastik yang dibuat Bata Ringan, sehingga masyarakat Kota Semarang maupun industri Bata Beton dapat memanfaatkan limbah plastik untuk pembuatan Bata Ringan. Dengan demikian diharapkan dapat kerjasama semua pihak, diantaranya

Perguruan Tinggi (Polines) sebagai institusi yang mempunyai kewajiban untuk melakukan Tri Darma Perguruan Tinggi dengan melalui kegiatan penelitian dan pengabdian kepada masyarakat, (2) Pemerintah Kota Semarang sebagai penanggung jawab Pemerintahan Daerah yang bertanggung Jawab mengelola daerahnya, dan (3) Masyarakat kota Semarang sebagai masyarakat social yang dalam kehidupan sehari-hari tidak lepas dari permasalahan sampah plastik dan dari permasalahan tersebut diharapkan dapat menyelesaikannya untuk dibuat bahan bangunan Bata Ringan.

Penelitian ini berawal dari mengingat bahwa kota Semarang mendapat permasalahan limbah plastik yang apabila tidak mulai diatasi akan menjadi permasalahan dimasa yang akan datang, sehingga peneliti tertarik untuk meneliti dengan judul "Pengaruh penambahan limbah plastik jenis thermosetting terhadap mutu Bata Ringan (Hebel)", walaupun kemungkinan penelitian serupa tentang Bata Ringan sudah banyak diteliti. Sehingga dapat ditarik kesimpulan sebagai berikut :

a) Dalam rangka sosialisasi Perda No.6 Tahun 2012 yang disampaikan oleh Wali Kota Semarang dan persoalan sampah yang sudah menjadi masalah serius di Kota Semarang sampai produksi sampah di Kota Semarang mencapai 1.200 ton/hari;

b) Karena adanya faktor keterbatasan Dinas Kebersihan dan Pertamanan Kota Semarang, tentang peranannya menangani masalah sampah dari limbah plastik;

c) Bagaimana jika dengan menambahkan limbah plastik yang dibuat variasi campuran dibuat Bata Ringan dan seberapa besar pengaruhnya terhadap kekuatan tekannya, sehingga hasil penelitian ini diharapkan dapat membantu dan bermanfaat bagi masyarakat 
Kota Semarang dalam pemanfataan limbah plastik.

\section{METODE PENELITIAN}

Tahapan penelitian diatas dapat dibagidalam 3 (tiga) tahap, antara lain mulai dari menganalisis material bahan susun sampai dengan menyusun proporsi dan menguji kekuatan tekan Bata Ringan. Batako dibuat dari bahan 1 bagian berat Semen Portland dengan 2 bagian berat Agregat (Pasir) ditambah dengan 10 variasi proporsi (10 variasi campuran Bata Ringan (BN), Bata Ringan dengan limbah plastik 1,0\% (B1,0); 2,0\% (B2,0); $3,0 \% \quad(\mathrm{~B} 3,0) ; \quad 4,0 \% \quad(\mathrm{~B} 4,0) ; \quad 5,0 \%$ $(\mathrm{B} 5,0) ; 6,0 \% \quad(\mathrm{~B} 6,0) ; 7,0 \% \quad(\mathrm{~B} 7,0)$; 8,0\% (B8,0); 9,0\% (B9,0); dan 10,0\% (B10); terhadap berat Pasir (Agregat Halus), semua bahan dalam kondisi kering oven. Sedang air yang dipergunakan dalam campuran ini adalah $50 \%$ dari berat semen (fas = 0,50) Demikian halnya pemakaian Foam Agent atau pasta alumunium (Admixture) sebagai bahan pengembang menggunakan ketentuan sesuai dengan aturan pemakaian untuk $1 \mathrm{~m}^{3}$ Bata Ringan.

(1) Tahap I : Menguji sifat fisis dan mekanis bahan susun Bata Ringan, seperti : pasir;

(2) Tahap II : Perhitungan campuran rencana (Mix Design), dalam penelitian ini akan dilakukan untuk mendapatkan komposisi bahan susun Adukan berdasarkan benda uji Bata Ringan ukuran $400 \mathrm{~mm} x$ $200 \mathrm{~mm} \times 100 \mathrm{~mm}$;

(3) Tahap III : Uji eksperimental kekuatan tekan sejumlah benda
Bata Ringan dengan berbagai durasi (lama) umur uji 28 hari.

\section{Persiapan Bahan dan alat}

a. Bahan-bahan yang dipakai dalam penelitian ini adalah :

1) Semen Portland, dalam penelitian ini menggunakan Portland Pozolan Cement (PPC) Jenis I - PU produk Gresik, yaitu semen yang digunakan secara umum di masyarakat;

2) Agregat halus ( pasir), pasir yang dipakai dalam penelitian ini adalah pasir Muntilan;

3) Pasta Aluminium (Admixture), Air Entraining Agent yang dipakai dalam penelitian ini adalah produksi $A D T$;

4) Limbah Plastik, limbah plastik yang dipakai dalam penelitian ini adalah hasil limbah plastik dilingkungan kota Semarang;

5) Air, air diambil dari laboratorium Politeknik Negeri Semarang.

b. Alat yang dipergunakan

a) Ayakan, dipakai untuk memisahkan fraksi-fraksi agregat menurut kelompok butiranya. Dalam penelitian ini digunakan satu set ayakan dari lubang mulai dari $\varnothing$ : $0,15 \mathrm{~mm}$ sampai dengan $\varnothing$ : $4,75 \mathrm{~mm}$;

b) Timbangan, dipakai untuk menimbang air, semen, fly ash dan pasir serta limbah plastik 
berupa serat sebelum bahanbahan dicampur, dengan ketelitian 1 gram;

c) Gelas ukur, dipakai untuk mengukur volume air;

d) Cetakan Bata Beton atau Bata Ringan, digunakan untuk mencetak benda uji dengan ukuran sisi $400 \mathrm{~mm}$ x $200 \mathrm{~mm}$ x $100 \mathrm{~mm}$;

e) Mesin pengaduk (Mixer), digunakan untuk mencampur dan mengaduk mortar kapasitas 5 liter;

f) Mesin cutter, digunakan untuk mencacah limbah plastik menjadi serat-serat (agregat);

g) Mesin uji tekan, digunakan untuk menguji kuat tekan beton, merk WF kapasitas $500 \mathrm{kN}$.

\section{Prosedur Penelitian}

Pelaksanaan penelitian dimulai dari pemeriksaan bahan susun sampai dengan pengujian kuat tekan benda uji. Secara garis besar meliputi :

a) Pemeriksaan agregat halus dan agregat kasar : Analisa saringan agregat, Berat jenis dan penyerapan air agregat, Kadar air agregat, Kadar butir halus lewat saringan no. 200, Kadar organik agregat dan Berat isi agregat;

b) Perhitungan rencana campuran (Mix Design). Metode perhitungan menggunakan cara untuk mendapatkan Bata Ringan, dengan masing-masing variasi durasi umur uji terdiri dari masing-masing 5 sampel dengan ukuran $400 \mathrm{~mm} \mathrm{x}$
$200 \mathrm{~mm}$ x $100 \mathrm{~mm}$, sehingga total benda uji sebanyak 55 buah;

c) Pencampuran dan pengadukan. dalam campuran ini untuk setiap macam bahan dan faktor air semen yang sama $(0,50)$ dibuat dalam satu adukan, dibuat 5 buah benda uji, yang akan diuji tekan pada umur 28 hari dengan banyak benda uji masing-masing umur 5 buah. Setelah bahan siap, kemudian dicampur dan diaduk dengan mesin mixer kurang lebih 3 - 4 menit;

d) Pencetakaan, adukan dimasukkan dalam cetakan benda uji dalam konsistensi normal (fas $=0,50$ ) dan Foam Agent setelah dicetak dibiarkan mengeras di ruang perawatan terbuka pada suhu ruang;

e) Perawatan, cetakan dibuka setelah dibiarkan selama 24 jam yang kemudian diberi tanda (kode) sesuai dengan cara penyiraman;

f) f) Pengujian, benda uji Bata Ringan diuji kekuatan tekannya pada umur 28 hari. Sebelum diuji Bata Ringan ditimbang, diukur dimensinya, kemudian diuji dengan mesin tekan dengan kecepatan 2,0 $-4,0 \mathrm{~kg} / \mathrm{cm} 2$ per detik dan dicatat beban tekan maksimumnya.

\section{Pengumpulan data}

Data penelitian diambil dari hasil pemeriksaan dilaboratorium terhadap bahan agregat halus, dan pengujian kuat tekan Bata Ringan. Hasil pemeriksaan laboratorium terhadap agregat halus, selanjutnya dicampur yaitu perbandingan air : semen : pasir, fly ash dan limbah plastik. Selanjutnya, 
dengan diketahui perbandingan berat campuran Bata Ringan (semen, pasir, fly ash dan limbah plastik) dengan penambahan limbah plastik $(1,0 ; 2,0$; 3,$0 ; 4,0 ; 5,0 ; 6,0 ; 7,0 ; 8,0 ; 9,0$ dan $10,0) \%$ dari berat pasir dengan faktor air semen (fas $=0,50$ ), pengujian kuat tekan (ditetapkan) umur 28 hari, serta jumlah pada setiap jenis/model benda uji (ditetapkan 5 buah). Maka akan diperoleh data pengujian kuat tekan sejumlah 5 benda uji pada setiap variable tetap +5 benda uji pada setiap variable bebas (limbah plastik) x $10=$ 50 benda uji, dan data total pengujian kuat tekan $=55$ benda uji .

\section{Analisis data}

Persamaan-persamaan dasar yang dipergunakan, adalah :

Kuat Tekan Beton $\left(\sigma^{\prime} \mathrm{b}\right)=\frac{P}{A}$

Dimana :

$\mathrm{P}=$ beban maksimum $(\mathrm{Kg})$

A = luas penampang benda uji $\left(\mathrm{cm}^{2}\right)$
Pengaruh penambahan limbah plastik terhadap kekuatan tekan dapat dilihat dari nilai kuat rata-rata masing-masing jenis campuran yang tanpa limbah plastik dengan yang menggunakan limbah plastik pada setiap interval $1,0 \%$ dari berat agregat, dengan umur uji 28 hari. Dengan analisis statistik yaitu uji hypotesis, dalam penelitian ini menggunakan analisis regresi berganda, karena analisis regresi digunakan untuk mengetahui seberapa besar hubungan antara variabel bebas dengan variabel terikat.

\section{HASIL DAN PEMBAHASAN}

\section{Hasil Pengujian Material}

Pengujian material dilakukan dengan menggunakan acuan standar uji Standar Nasional Indonesia (SNI) atau ASTM (jika pada salah satu diantara jenis uji tertentu tidak terdapat dalam SNI), pengujian sifat - sifat material meliputi : uji agregat halus, fly ash dan Semen Portland dengan hasil seperti dalam tabel 1.

Tabel 1. Hasil penelitian sifat fisik dan mekanis agregat

\begin{tabular}{|c|l|c|c|l|}
\hline$N_{0}$ & \multicolumn{1}{|c|}{ Jenis material } & Hasil pengujian & Spesifikasi & Keterangan \\
\hline 1 & Agregat Halus (Pasir) & & & \\
\hline a & Indeks kekerasan & & $\leq 2,2$ & Tidak diuj \\
\hline b & Kekekalan & $3,57 \%$ & Maksimum 12 \% & Memenuhi \\
\hline c & Kadar butir halus lewat saringan no. 200 & $4,10 \%$ & Maksimum 5 \% & \\
\hline d & Kadar organik & Tidak ada & Tidak boleh ada & Memenuhi \\
\hline e & Analisa ayak & & & \\
\hline & Angka kehalusan butir (Fineness modulus) & 2,66 & $1,5-3,8$ & Memenuhi \\
\hline & Daerah susunan butir & Zone 2 & Zone 1,2,3 atau 4 & \\
\hline f & Reaksi alkali agregat & & Negatif & Tidak diuji \\
\hline g & Berat Jenis & 2,63 & 2,5 & Memenuhi \\
\hline h & Penyerapan Air & $1,21 \%$ & 3 & Memenuhi \\
\hline i & Kadar Air & $3,36 \%$ & - & \\
\hline 2 & Semen Portland & & & \\
\hline a & Berat Isi & 1,25 & $>1,25$ & Memenuhi \\
\hline 4 & Abu Batubara (Fly Ash) & & & \\
\hline a & Berat Isi & 1,12 & & \\
\hline
\end{tabular}




\section{Hasil Pemeriksaan Sifat Fisik Agregat}

Dengan hasil pengujian material agregat yang berasal dari pasir Muntilan seperti diatas, maka agregat tersebut dinyatakan "dapat digunakan" sebagai campuran Bata Ringan, Foam Agent dari ADT Product dan semen portland (PC) dalam penelitian ini menggunakan PPC Jenis I - PU ex Gresik. Agregat dinyatakan dapat dipergunakan untuk campuran bata beton berlubang dan dari semua hasil pengujian sifat fisik/mekanis menunjukkan memenuhi persyaratan seperti yang tercantum dalam SNI 03 6861.1-2002 atau Spesifikasi A untuk Bahan Bangunan non Logam.

$$
\text { Berdasarkan pengujian }
$$

Kekekalan bentuk agregat terhadap larutan Natrium atau Magnesium Sulfat (Soundness), dimana uji ini adalah salah satu cara uji dengan cara percepatan dan mempunyai tujuan untuk mengetahui sampai sejauhmana agregat dapat dinyatakan tahan dari pengaruh cuaca tanpa terjadinya deformasi, serta jika hasil menunjukkan dibawah persyaratan, maka agregat tersebut dapat dinyatakan tahan terhadap pengaruh cuaca (Durable). Dari hasil uji didapat $3,57 \%$ untuk agregat halus atau lebih kecil dari $12 \%$, berarti pasir Muntilan memenuhi syarat ketahanan terhadap pengaruh cuaca.

Uji Material lolos saringan no. 200 bertujuan untuk mengukur kandungan bahan impurities yang terdapat pada agregat. Material yang dimaksudkan adalah lumpur, lanau, tanah liat yang mempunyai sifat tidak kekal yang dapat mengembang dan menyusut akibat pengaruh cuaca disamping menghalangi ikatan antara agregat terhadap semen Portland, sehingga dapat mengurangi kualitas beton terutama terhadap kekuatan tekan. Dalam uji ini material lolos saringan no. 200 dibatasi tidak boleh lebih dari 5\% untuk agregat halus, sedang hasil pemeriksaan agregat halus menunjukkan $4,10 \%<5 \%$ (memenuhi syarat).

Uji Berat Jenis dan penyerapan air adalah untuk mengukur agregat yang dipergunakan dalam penelitian ini dapat dipergunakan sebagai campuran Mortar. Agregat harus mempunyai Berat jenis lebih besar dari 2,63 sedang Penyerapan airnya tidak boleh melebihi dari 1,21\%. Dari agregat yang diuji menunjukkan Berat jenisnya 2,63 lebih besar dari 2,5 dan Penyerapan airnya $1,21 \%$ lebih kecil dari $3 \%$ pada agregat halus, artinya bahwa agregat ini dapat dipergunakan untuk penelitian.

Dari uji Analisa ayak agregat halus termasuk kasar, karena berada didaerah zone 2 disamping mempunyai Angka kehalusan butir 2,66, berada pada angka kehalusan butir antara 1,5 s.d. 3,8. Jadi secara umum agregat halus yang dipergunakan dalam penelitian dapat dipergunakan untuk aduk bata beton berlubang, karena secara garis besar persyaratan fisik memenuhi persyaratan sebagai agregat.

\section{Hasil Pemeriksaan Semen Portland} Semen Portland dalam penelitian ini tidak diuji mengingat semen dalam fabrikasi telah lolos Quality Controll, 
hanya diuji terhadap Berat isi didapat $1,25 \mathrm{~kg} / \mathrm{lt}$.

\section{Hasil Pemeriksaan Terbang (fly ash)}

Abu Terbang (fly ash), memiliki Berat isi $1,14 \mathrm{~kg} / \mathrm{lt}$ dengan kehalusan butir lolos no. 200

\section{Analisa Kebutuhan Bahan}

Analisa kebutuhan bahan campuran adukan rencana didasarkan pada Tata cara membuat rancangan campuran Mortar (Mix design) di Indonesia terdapat dalam SNI 03 - 6882 - 2002, dan terbatas untuk rancangan campuran adukan dengan kondisi menunjukkan kadar air. Sedang bahan perekat menggunakan Semen Portland jenis I - PU ex PT. Semen Gresik, agregat alam dari pasir Muntilan yang secara umum banyak dipergunakan untuk pembuatan bermacam-macam aduk. Dalam penelitian ini menggunakan perbandingan bahan 1 PC : 2 PS (Kadar air 3,36\%), dan air dengan fas antara 0,50. Sedangkan pembuatan Busa dengan cara pada aturan pemakaian dari Produsen yang membatasi dengan perbandingan untuk $400 \mathrm{mml}$ Foam Agent : $2000 \mathrm{mml}$ air. Untuk sekali trial mix 3 buah benda uji, menggunakan komposisi campuran seperti dalam tabel 2 .

\section{Hasil pengujian kuat tekan}

Hasil uji kuat tekan Bata Ringan (Hebel) dari berbagai jenis campuran dan umur dapat dilihat dalam tabel 3 di bawah.

Tabel 2. Jenis Campuran dan susunan perbandingan bahan

\begin{tabular}{|c|c|c|c|c|}
\hline No. & Jenis Campuran & Semen (gr) & Pasir (gr) & Plastik (gr) \\
\hline 1 & Campuran "BN" ( limbah plastik 0\% ) & 3750.0 & 7500.0 & 0.0 \\
\hline 2 & Campuran "B1,0" (limbah plastik 1,0\%) & 3750.0 & 7500.0 & 75.0 \\
\hline 3 & Campuran "B2,0" (limbah plastik 2,0\%) & 3750.0 & 7500.0 & 150.0 \\
\hline 4 & Campuran "B3,0" (limbah plastik 3,0\%) & 3750.0 & 7500.0 & 225.0 \\
\hline 5 & Campuran "B4,0" (limbah plastik 4,0\%) & 3750.0 & 7500.0 & 300.0 \\
\hline 6 & Campuran "B5,0" (limbah plastik 5,0\%) & 3750.0 & 7500.0 & 375.0 \\
\hline 7 & Campuran "B6,0" (limbah plastik 6,0\%) & 3750.0 & 7500.0 & 450.0 \\
\hline 8 & Campuran "B7,0" (limbah plastik 7,0\%) & 3750.0 & 7500.0 & 525.0 \\
\hline 9 & Campuran "B8,0" (limbah plastik 8,0\%) & 3750.0 & 7500.0 & 600.0 \\
\hline 10 & Campuran "B9,0" (limbah plastik 9,0\%) & 3750.0 & 7500.0 & 675.0 \\
\hline 11 & Campuran "B10" (limbah plastik 10\%) & 3750.0 & 7500.0 & 750.0 \\
\hline
\end{tabular}

\section{Catatan :}

Semua jenis campuran dengan air seberat 1875 gram dari berat Semen Portland (fas : 0,50). 
Tabel 3.Hasil uji tekan Bata Ringan berbagai jenis campuran

\begin{tabular}{|c|c|c|c|c|c|c|c|c|c|}
\hline \multirow{3}{*}{$\begin{array}{c}\text { No } \\
\text { benda } \\
\text { uji }\end{array}$} & \multirow{3}{*}{$\begin{array}{c}\text { Kode } \\
\text { benda } \\
\text { uji }\end{array}$} & \multirow{3}{*}{$\begin{array}{l}\text { Ukuran } \\
\text { benda } \\
\text { uji }(\mathrm{cm})\end{array}$} & \multirow{3}{*}{$\begin{array}{l}\text { Berat } \\
(\mathrm{kg})\end{array}$} & \multirow{3}{*}{$\begin{array}{l}\text { Berat isi } \\
\left(\mathrm{kg} / \mathrm{dm}^{3}\right)\end{array}$} & \multirow{3}{*}{$\begin{array}{c}\text { Luas } \\
\text { permukaan } \\
\left(\mathrm{cm}^{2}\right)\end{array}$} & \multirow{2}{*}{\multicolumn{2}{|c|}{ Tanggal }} & \multirow{3}{*}{$\begin{array}{l}\text { Umur } \\
\text { (hari) }\end{array}$} & \multirow{3}{*}{$\begin{array}{r}\text { Kuat tekan } \\
\text { rata-rata } \\
\left(\mathrm{kg} / \mathrm{cm}^{2}\right)\end{array}$} \\
\hline & & & & & & & & & \\
\hline & & & & & & Pembuatan & Uji & & \\
\hline 1 & BN.1 & $40 \times 20 \times 10$ & 12,030 & 1,504 & 800,00 & 20-Jul-19 & 17-Agust-18 & 28 & 17,98 \\
\hline 2 & $\mathrm{~B} 1,0$. & & 11,790 & 1,474 & & 20-Jul-19 & 17-Agust-18 & 28 & 17,12 \\
\hline 3 & B2,0. & & 11,630 & 1,454 & & 20-Jul-19 & 17-Agust-18 & 28 & 15,33 \\
\hline 4 & B3,0. & & 11,230 & 1,404 & & 06-Agust-19 & 03-Sep-19 & 28 & 14,03 \\
\hline 5 & $\mathrm{~B} 4,0$. & & 11,360 & 1,420 & & 06-Agust-19 & 03-Sep-19 & 28 & 13,64 \\
\hline 6 & B5,0. & & 11,310 & 1,414 & & 06-Agust-19 & 03-Sep-19 & 28 & 13,24 \\
\hline 7 & $\mathrm{~B} 6,0$. & & 11,230 & 1,404 & & 06-Agust-19 & 03-Sep-19 & 28 & 12,88 \\
\hline 8 & $\mathrm{~B} 7,0$. & & 11,190 & 1,399 & & 06-Agust-19 & 03-Sep-19 & 28 & 12,31 \\
\hline 9 & B8,0. & & 11,010 & 1,376 & & 06-Agust-19 & 03-Sep-19 & 28 & 12,26 \\
\hline 10 & B9,0. & & 10,140 & 1,268 & & 06-Agust-19 & 03-Sep-19 & 28 & 12,16 \\
\hline 11 & B10,0. & & 10,066 & 1,258 & & 06-Agust-19 & 03-Sep-19 & 28 & 9,88 \\
\hline
\end{tabular}

\section{Pembahasan}

Hasil pengujian kuat tekan Bata Ringan (Hebel) dari berbagai jenis campuran pada umur 28 hari, dapat ditabelkan seperti dalam tabel 3 diatas yang menggambarkan hubungan antara Kuat Tekan Bata Ringan (Hebel) dengan Campuran mulai dari tanpa penambahan Plastik setiap beda $1 \%$ mulai dari $1 \%$ sampai dengan $10 \%$. Hasil pengujian terhadap Kekuatan tekan Bata Ringan (Hebel) dari berbagai jenis campuran, dapat dilihat seperti pada tabel 4.

Pengaruh penambahan Plastik terhadap kekuatan tekan Bata Ringan (Hebel) dapat dilihat pada gambar hubungan kuat tekan rata-rata, umur, dan jenis campuran pada Gambar 1, dengan persamaan regresi $\mathrm{Y}=0,042 \mathrm{X}^{2}$ - 1,177 X + 18,84 dengan nilai korelasi $\mathrm{R}^{2}=0,934$ yang artinya terdapat hubungan yang "kuat" antara kuat tekan Bata Ringan (Hebel) dengan atau tanpa campuran Plastik dengan berbagai jenis komposisi campuran yang diuji umur 28 hari, karena nilai $\mathrm{R}^{2}$ berada antara $0,80-1,0$. Pengaruh penambahan Plastik setiap beda $1 \%$, nilai kuat tekan rata-rata turun dimulai dari penambahan $1 \%$ sampai dengan $10 \%$. Hasil uji dari semua kekuatan tekan rata-rata sampai dengan penambahan Plastik sebesar 10\% dapat dilhat pada tabel 4 .

Kuat tekan rata-rata tertinggi pada penambahan Plastik 1,0\% dengan kekuatan tekan $17,12 \mathrm{~kg} / \mathrm{cm}^{2}$, sedang yang terendah pada penambahan Plastik 10,0\% dengan kekuatan tekan $9,88 \mathrm{~kg} / \mathrm{cm}^{2}$. Dari analisa ini dapat dilihat bahwa dengan penambahan Plastik setiap beda $1 \%$ s.d. $10,0 \%$ mempunyai pengaruh kuat tekan ratarata yang menurun dibanding dengan Bata Ringan (Hebel) tanpa penambahan Plastik. 
Tabel 4. Hubungan antara Jenis campuran dengan Kuat Tekan Bata Ringan (Hebel) pada umur 28 hari.

\begin{tabular}{|c|l|c|c|}
\hline \multirow{2}{*}{ No. } & \multirow{2}{*}{ Jenis Campuran } & Kuat Tekan rata-rata, kg/cm² & \multirow{2}{*}{ Keterangan } \\
\cline { 3 - 4 } & & 28 hari & \\
\hline 1 & Campuran "BN" (limbah plastik 0\%) & 17,98 & \\
\hline 2 & Campuran "B1,0" (limbah plastik 1,0\%) & 17,12 & \\
\hline 3 & Campuran "B2,0" (limbah plastik 2,0\%) & 15,33 & \\
\hline 4 & Campuran "B3,0" (limbah plastik 3,0\%) & 14,08 & \\
\hline 5 & Campuran "B4,0" (limbah plastik 4,0\%) & 13,64 & \\
\hline 6 & Campuran "B5,0" (limbah plastik 5,0\%) & 13,24 & \\
\hline 7 & Campuran "B6,0" (limbah plastik 6,0\%) & 12,88 & \\
\hline 8 & Campuran "B7,0" (limbah plastik 7,0\%) & 12,36 & \\
\hline 9 & Campuran "B8,0" (limbah plastik 8,0\%) & 12,26 & \\
\hline 10 & Campuran "B9,0" (limbah plastik 9,0\%) & 12,16 & \\
\hline 11 & Campuran "B10" (limbah plastik 10\%) & 9,88 & \\
\hline
\end{tabular}

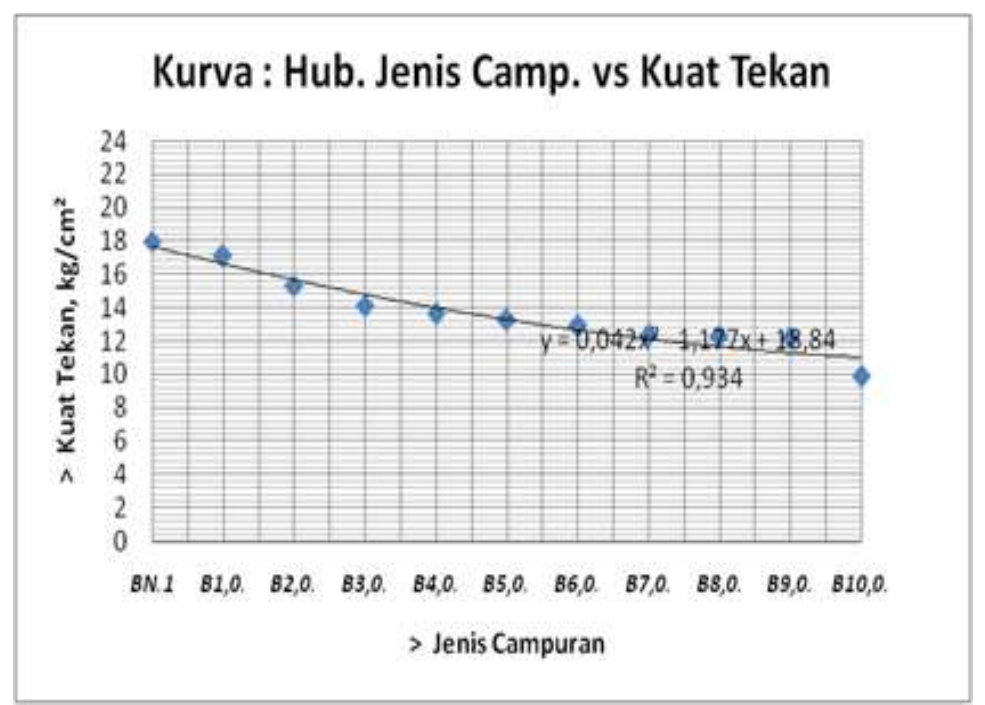

Gambar 1. Hubungan antara Jenis campuran dengan Kuat Tekan

Bata Ringan (Hebel) pada umur 28 hari.

\section{SIMPULAN}

Dari hasil analisa dan pembahasan di atas dapat disimpulkan bahwa secara umum Bata Ringan (Hebel) yang dengan penambahan Plastik beda setiap $1 \%$ sampai $10 \%$, menunjukkan Kekuatan Tekan rata-ratanya menurun. Kuat tekan rata-rata tertinggi sebesar $17,12 \mathrm{~kg} / \mathrm{cm}^{2}$ pada penambahan Plastik
$1,0 \%$ dan terendah $9,88 \mathrm{~kg} / \mathrm{cm}^{2}$ pada penambahan Plastik 10\%. Pengaruh penambahan Plastik setiap beda $1,0 \%$ yang terjadi adalah penurunan kuat tekan rata-ratanya, hal ini dapat disebabkan karena bahan plastik ini merupakan bahan limbah yang masih dapat digunakan walaupun dampaknya menurunkan kekuatan tekan rata- 
ratanya. Pengaruh penambahan Plastik dalam Bata Ringan (Hebel) terbukti menurunkan kuat tekan rata-ratanya pada setiap penambahan $1,0 \%$ sampai dengan 10,0\% dan Kuat tekan terendah $9,88 \mathrm{~kg} / \mathrm{cm}^{2}$.

\section{UCAPAN TERIMA KASIH}

Penulis mengucapan terima kasih kepada kepala Unit Penelitian dan Pengabdian kepada Masyarakat (P3M) Politeknik Negeri Semarang dan seluruh staf yang terkait yang telah membantu memberi informasi pelaksanaan penelitian, kepada ketua Laboratorium Bahan Bangunan Jurusan Teknik Sipil yang telah merekomendasi penggunakan peralatan laboratorium dan memfasilitasi segala keperluan pelaksanaan, tenaga laboran, serta semua pihak yang telah membantu hingga penelitian ini berjalan lancar.

\section{DAFTAR PUSTAKA}

Ahmad Wancik, Iman Satyarno, Kardiyono Tjokrodimulyo, 2008, Pengaruh Styroform pada Komposit mortar.

American Society for Testing and Material, 1997, Annual Book of ASTM Standards,Vol.04.02, Concrete and Aggregates, Philadelphia : ASTM.

Anto Dajan, 1996, Pengantar Statistik Jilid II, Lembaga Penelitian Pendidikan dan Penerangan Ekonomi dan Sosial, Jakarta

Dedy Sumaryanto, Iman Satyarno, Kardiyono Tjokrodimulyo, 2009, Batako Sekam Padi Mortar Semen.
Departemen Permukiman dan Prasarana Wilayah, Badan Penelitian dan Pengembangan Wilayah, Badan Penelitian dan Pengembangan Kimpraswil, Standar Nasional Indonesia, 2002, Metode, Spesifikasi dan Tata Cara Bagian 2 : Batuan Sedimen, Agregat, Departemen Kimpraswil, Jakarta

Departemen Permukiman dan Prasarana Wilayah, Badan Penelitian dan Pengembangan Wilayah, Badan Penelitian dan Pengembangan Kimpraswil, Standar Nasional Indonesia, 2002, Metode, Spesifikasi dan Tata Cara Bagian 3 : Beton, Semen, Perkerasan Beton Semen, Departemen Kimpraswil, Jakarta

D.C. Teychene, 1982, Design of Normal Concrete Mixes, London, Departement of Environment, Building Research Establishment, Transport and Road Research Laboratory

Ghozali, Imam, 2009, Aplikasi Analisis Multivariate dengan program SPSS, Cetakan IV, Badan Penerbit Universitas Diponegoro, Semarang Hendy Febriyatno, 2012, Pemanfaatan Limbah Bahan Padat Sebagai Agregat Kasar Pada Pembuatan Beton Normal, Universitas Gundarma, Jakarta, 09 Februari 2012

Haryoshi Utami, 2011, Pengaruh Perendaman Beton PC I PT. Semen Padang dalam air laut 
dan air tawar terhadap sifat

Kuat Tekan, FMIPA

Universitas Andalas, Padang

Izzudin, Ary Setyawan, SA Kristiawan, 2014, Pengaruh

Penambahan Serat Limbah

Botol Plastik terhadap

Karakteristik Mekanik dan susut repair Mortar

Paul Nugraha, Antoni, 2007, Teknologi

Beton, Andi Offset, Yogyakarta

Polytechnic Educational Develepment

Center, 1987, Teknologi Bahan

1, Departemen Pendidikan dan

Kebudayaan,

Direktorat
Pendidikan Tinggi PEDC -

Bandung

Polytechnic Educational Develepment

Center, 1987, Teknologi Bahan

2, Departemen Pendidikan dan

Kebudayaan, Direktorat

Pendidikan Tinggi PEDC -

Bandung

Ritonga, Abdulrahman, 1987, Statistik

Terapan untuk Penelitian,

Lembaga Penerbit FE-UI,

Jakarta

Tjokrodimuljo K., 1996, Teknologi Beton, Naviri, Yogyakarta

Tri Mulyono, 2005, Teknologi Beton, Andi Offset, Yogyakarta 